\title{
A nevelési tanácsadás mint a korai intervenció fontos területe
}

\author{
Borbély Sjoukje \\ Budapesti Korai Fejlesztő Központ
}

\begin{abstract}
A tanulmány bemutatja a korai intervencióval, a rizikó- és/vagy sérült kisgyerekekkel foglalkozó szakemberek munkáját úgy, hogy e munkában hangsúlyozza a benne részt vevő felnőttek - a szülő és a szakember - kapcsolati dilemmáit. A korai intervenció müfaja különbözik más gyógypedagógiai munkától. A kisgyermek és szülöje csak akkor profitálhat belöle érdemben, amikor a szakember a szülőt is megnyerte a fejlesztéshez. Ez a gyakorlatban azt jelenti, hogy a szülö megértse, mi történik az órákban, együttmüködjön a szakemberrel, s ha szükség van rá, merjen segítséget kérni a saját otthoni szülői szerepgyakorlásával kapcsolatban. A tanácsadás célja egyrészt a fejlesztő munka beépitése a mindennapokba, másrészt az egyéb előforduló speciális nevelési gondok együttes átbeszélése. A tanácsadás kiegészítő tevékenység lehet, de időlegesen akár elötérbe is kerülhet, egy ideig helyettesitve az aktív fejlesztést.
\end{abstract}

Kulcsszavak: korai fejlesztés és intervenció, családi rendszer, trauma, játszma, önismeret, kommunikáció, partnerség

\section{Miről szól a korai intervenció?}

Nem minden gyermek születik egészségesen és időben.

Minden társadalomnak szembe kell nézni azzal a kérdéssel, hogy milyen segítséget tud adni a szülőknek, a családnak, amikor a várva várt baba nem feltétlenül örömöt okoz megérkezésékor, amiért nem ilyennek várták. Valami hibája van, vagy lehet, hogy van, vagy lesz. Netán a szülés maga okozta az ezt követő időszakot az összes bajával, amikor minden másképpen alakul, mint ahogyan a szülök - s velük az egész család - akarták volna. A szülés problematikusan zajlott talán, a gyermek túl sokáig volt a szülőcsatornában, vagy nem sírt fel, amikor megszületett. Esetleg eltérést mutatott külsőjében, s az orvosok vizsgálni kezdik, vagy a viselkedése révén tűnt fel, miután már megszületett. Igen nehéz időszakok ezek. A szülők feszülten várják a megnyugtató híreket, a kórházi személyzet viszont kerüli velük a közvetlen kapcsolatot, a konkrét kérdéseket a részükröl.

Egy újszülött gyermek szülei, addig, amíg a gyermek orvosi segítségre szorul, orvosi diagnózisra vár, igen kiszolgáltatott állapotba kerülhetnek. Idővel azonban orvosi téren valamiféle felvilágosítás, megmondás mégiscsak megtörténik (Gyertyánági, 1995). Jelenleg még az orvosok személyiségén, az osztály hangulatán múlik az, hogy milyen esetekben, milyen körülmények között, milyen szinten tájékoztatják a szülőket a várható dilemmákról. Egységes protokoll, ami a kórházi mentálhigiénia természetes része lenne, még mindig nincs a kórházainkban.

A kórházban töltött időszak után a problémás gyerekek szüleinek kiszolgáltatottsága általában fokozódik. Az orvosok ezután már csak nyomon fogják kísérni a sorsukat, jobb esetben átadják őket valamilyen, a korai fejlesztéssel foglalkozó cégnek, alapítványnak. Ezzel kezdődik a szülök nehéz útjának a második stációja. Gyakran a véletlenen múlik az, hogy melyik szülő melyik gyerekkel melyik szakembergárdához kerül, s a még egy ideig nehezen körvonalazható problémájára milyen szakember vagy szakembergárda milyen gyógyírt ajánl, milyen fejlesztő, terápiás beavatkozásban szeretné a gyereket részesíteni, s milyen szerepet szán ebben a gyermek szüleinek. 
A kezdetben még csak orvosi problémák idővel részben más jellegű, pedagógiai problémává válhatnak tehát, hiszen ott, ahol az elmaradás, eltérés vagy sérülés orvosilag nem befolyásolható, most már csak ök segíthetnek. Itt jöhetnek a nem orvosi gyógy szakemberek képbe, tehát, elsősorban a gyógypedagógusok és a gyógytornászok.

Az érintett szülők tehát egyrészt kiszolgáltatottá válnak, amennyiben lelkiismeretük és környezetük azt sugallja nekik, hogy tegyenek meg mielöbb mindent, amit tudnak a gyermekük fejlödése érdekében, másrészt örülhetnek a kapaszkodóknak, a segítő szakemberek speciális tudásának. Jó esetben viszonylagos biztonságban tudják magukat az új szakemberek környezetében.

Csakhogy akarva, nem akarva nagyok az elvárások. A szülöknek fogalmuk sincs arról, hogy ebben a stációban, amiben a mütét vagy a gyógyszer már nem segíthet, milyen sok türelem és fáradtság révén születhetnek meg a várva várt teljesítmények. Maga a gyógypedagógia és a fejlesztés fogalmai is félrevezethetők lehetnek, s melyik - ilyen helyzetbe kerülő- szülő ne hagyná szívesen félrevezetni magát?

\section{A korai fejlesztés első időszaka}

A változások, amelyek a korai intervenció területén végbementek, amiért most már a tanácsadás is egy aktuális intervenciós formává válik, tulajdonképpen egy természetes folyamat eredményei. Egy folyamat, amelyben a korai fejlesztés önálló terület lett, de még anélkül, hogy a dolog eredményességéről érdemben lehetett volna beszélni. Kezdetben, nyugaton a múlt század 60-as éveitől, hazánkban kb. a 80-as évektől, feltételezések azért voltak. A fejlesztés célja lehetőleg a felzárkóztatás volt, az átlagos fejlödés elérése, vagy megközelítése. Ez akkor is így volt, amikor a szakemberek már tudták, hogy a probléma megszüntetése pl. orvosilag dokumentált szindrómák esetén, nem reális cél. A szülő saját problémája, hogy meg tudjon birkózni a nehéz helyzetével, akkor még háttérben maradt.

A korai gyógypedagógiai segítségnyújtás kezdetben is - elvben- messzemenően humánus volt. Végre a másképpen fejlődő kisgyerek szülője is kaphatott szakmai segítséget, nem kellett az óvodás vagy iskolás korig várni ezzel... Viszont csakhamar kiderült - külföldön és itthon egyaránt -, hogy nem minden szülő lett jó tanítvány, és nem minden gyerek reagált egyértelműen jól, fejlődött jobban a gyógypedagógusok és gyógytornászok segítségével. Mind a két oldalon csalódások voltak tehát, a szülők és a szakemberek oldalán egyaránt, amelyek csalódások külföldön hamarabb fogalmazódtak meg, mint itthon (Kedl és Borbély, 1991).

Külföldön - talán először Hollandiában és Németországban - miután kiderült, hogy a két fél közötti kommunikáció gyakran döcög, a szülő nem bizonyult elég jó tanítványnak és a gyerek nem fejlödött elég jól, a helyzet kölcsönös elégtelenséget eredményezett. Megoldásként a szándék született arra, hogy a szülöt a saját szülői tapasztalatai alapján békében és tiszteletben tartsák, tapasztalati terapeutaként (Erfáhrungsspecialist-ként) elfogadják, és értékeljék. Ez szépen hangzott ugyan, de ez az átminősítés sem hozott valódi megoldást a kommunikációs dilemmákat illetően. Sőt. Mind a két fél - a szülő is és a szakember is- tehette a maga dolgát, tisztelték egymást, de nem volt miről beszélni. A gyermek otthoni nevelése és szakember általi fejlesztése két különböző területté változott. A felek e keretben az egyenlőség alapján találkoztak ugyan, jó esetben egymást respektálva, de nem ugyanazon „dolgozva”. „A szülő csak maradjon szülö!" szlogenben a szülő nem kapott tehát segítséget a sajátos igényủ gyermeke neveléséhez. 
Ez a fajta együttműködés tehát nem lett igazán hatékony, a kétségtelen demokratikus hozzáállás ellenére sem. Ráadásul sok energia megy kárba, ha nem foglalkozunk a felnőttek kapcsolatával, hiszen rajtuk és a kapcsolatukon múlik a gyerek jóléte. Talán az utóbbit, az optimális kapcsolatot szülök és szakemberek között kerestük, amikor a Budapesti Korai Fejlesztő Központban a célkitűzéseink megváltoztak. Kerestük a hatékonyságot, az érdembeli szülö-szakember kapcsolatot, amiben több van, mint egymás kölcsönös tiszteletben tartása. Be kellett látnunk, hogy az egyéni korai fejlesztés nem tanári, hanem kifejezetten terápiás munka. A szakemberek kezeiben ott lehetnek a tanult szakmai irányelvek, és a munkájuk tartalma is részben adott, de a tudásukat gyerekenként és családonként lehet csak adagolni, hozzájuk és a problémájukhoz alkalmazkodva. Amikor fejlesztenek, direkt hatnak a gyermek viselkedésére, amikor a szülőknek tanácsokat szeretnénk adni, indirekt módon hatnak az egész családi rendszerre. Az első megsegítési forma egyszerübbnek tünik, de nem mindig elég hatékony. A másik forma, bár összetettebb, sikeresebb lehet. Nem ritkák azonban a megtorpanások a felek kapcsolattartásában, kialakulnak kommunikációs dilemmák.

\section{Mindenki másképp csinálja}

Mind tudjuk, szakterület szerint különböznek a célkitűzések arra vonatkozóan, hogy mi történjen a lassan, vagy eltérően fejlődött gyerekkel a fejlesztő órák során. Ezért van az, hogy föleg a mozgásterápiák területén, gyakran szükség van a szakemberek által javasolt konkrét szülői munkára. A Dévény féle mozgásterápiában pl. a szülő jelenléte önmagáért fontos, de nem segít, és nem visz haza házi feladatot. Ő „csak” a gyerekkel együtt akár szenvedő alanya a terápiának. Az ún. TSZMT terápiákban a szülők egyszerre lesznek a szakemberek tanítványai és a tananyag kivitelezői, amikor hazavisznek egy programot otthoni használatra (Borbély, 2008. 51-73.).

Vagyis, e jellegü, elsősorban a gyermek mozgásában beavatkozó terápiák területén kétségtelenül más az alaphelyzet, mint amikor egy szülő gyógypedagógiai segítséget kér, vagy mások szerint erre szorul rá.

Nem minden gyógyító szakember - aki nem orvos - gondolja végig ezeket a kérdéseket, amikor még csak készül a feladatra, hogy a korai intervenció területén szeretné a tudását hasznosítani. Módszertani fogásokban gondolkodik, programokban, súlyosan és kevésbé súlyosan érintett gyermekekben, eredményekben és lehetséges megtorpanásokban. Mindezt szakmájából kiindulva teszi, ritkán készül fel arra, hogy egy speciális helyzetbe kerülhet ő akkor, amikor találkozni fog olyan szülőkkel is, akiknek még egyáltalán nem evidens, hogy az ő gyermekük esetleg sérült személy lesz. Annak, aki a korai intervenció területen dolgozik, fontos lesz önmagával tisztázni azt, hogy mit gondol ő maga tulajdonképpen a munkája lehetséges hatékonyságáról, s mit szeretne, hogy a szülők mit gondolnának róla? Szeretné ő, hogy a szülő gondolja azt, hogy azért fejlődik egy gyermeke megfelelően, mert néhányszor egy héten eljön a fejlesztő központba őhozzá, vagy azt szeretné, hogy a szülő hazavigye azt, amit tapasztal, s a tudását az otthoni életükbe beépítve önmagának tulajdonítsa majd az eredményeket? Merthogy a korai intervenciót nyújtó központokban bizonytalan és szorongó szülőkkel fog találkozni, akik a maguk problémái miatt objektívan nem is ítélhetik meg a szakemberek munkáját. Jó, ha a szakember nem értékeli túl a saját kompetenciáját, s szeretne hozzájárulni ahhoz, hogy a szülő maga minél hatékonyabbnak élhesse meg önmagát. Ez utóbbi csak akkor lehetséges, amikor optimális kapcsolatra törekszik minden szülővel. Mert amikor a szülő elégedetlen, netán haragszik a fejlesztőre, azonnal megkérdőjeleződik a fejlesztés lehetséges hatékonysága. 


\section{Családok és szakemberek, együtt egy rendszerben}

A legtöbb esetben idővel tudatosul a szülőkben a gyermekük valós állapota, s felmérik a reális lehetőségeket, amikor a „baj” nem szívódik fel nyomtalanul, nem „hozza be” magát a gyermek. Rendszerszemléletben gondolkodva azt mondhatjuk ilyenkor, hogy a szülőkben végbemenő folyamatosan alakuló tudatosulással a segítő szakemberek nélkülözhetetlenné válnak, és így bekerülnek a családok alrendszereinek egyikébe. Azzal, hogy ők, a terapeuták, vannak, léteznek, és azzal, amit tesznek és mondanak, vagy nem tesznek s nem mondanak, fontos személyek lesznek. Bekerülnek a családokban végbemenő dinamikába, a családtagok mindennapjaiba.

Ahogyan a szakemberek még a soha nem látott édesapák életében is jelen lesznek, hiszen azok esetleg örülnek annak, hogy a feleségüknek legalább egy, vagy több valakije van, akivel a gyerekükről beszélhetnek, s ők így valamelyest mentesülnek a teher alól, az alól, hogy nekik a párjukkal együtt is kellene tudni beszélni a gyermekröl. De akkor is, amikor egy apa felesleges energia befektetésnek gondolhatja felesége szakemberekhez való járását, s ő maga nem jár oda, az apa a szakemberrel egy közös rendszerbe kerül anélkül, hogy a hozzá járó szülő egyáltalán megemlítené őt. Hiszen viszonyul hozzá, tudja, hogy van, és gondolatai vannak vele kapcsolatban. Az egyik szülő a másik szülő szemüvegén keresztül is értékelheti a korais világot, s az ott végbemenő eseményeket . A szakember nem tudhatja, hogy mi történik a családokban, de nem ritkán érzékeli a nem jelenlévő szülő vélekedéseit a jelen lévő szülőn keresztül.

Miként látják a szülők és szakemberek e speciális helyzetét a pszichológusok? Már csak kevés szakember indul ki abból a szemléletből, hogy egy sérült gyerek szülője csak sérült személyiség lehet, ahogyan ezt annak idején a pszichoanalitikusok állították (Balzer és Rolli, 1975). Most már inkább a feldolgozás nehézségeire, illetve a mindennapok ezer dilemmáira helyezik a hangsúlyt. Az időtényező - annak hangsúlyozása, hogy sok időre van szüksége, mire egy sérült gyerek szülője valamelyest elfogadja a helyzetét, van inkább előtérben. Viszont továbbra is „tartja” magát a szülők külső és belső érzelmi bizonytalanság, az érzelmi megosztottság hangsúlyozása, nem indokolatlanul. Az új helyzet felfogásához és részleges elfogadásához idő kell (Borbély, 2012. 63-89).

Úgy gondolom, s tapasztalom is rendszeresen, hogy nem várható, hogy egy sérült gyermek szülője szépen sorba járja az u.n. trauma feldolgozásának ismert fázisait. A sérült gyermek tudniillik él, s nincs halálra ítélve, mint ahogyan azok a betegek voltak, akik révén Kübler-Ross kidolgozta a traumaelméletét (1988). A „hibás” gyerekek, mivel élnek, az állandóan változó szükségleteikkel, akkor is gondozásra és fejlesztésre szorulnak, amikor a szülő nem fogadja el a helyzetét, a gyermeke sérült mivoltát.

Ez az alaphelyzet, a tény, hogy a gyermek léte töle, a szülötől függ, kezdetben nélkülözhetetlen tényező a későbbi elfogadáshoz. Sok szülö éppen a gyermeke kiszolgáltatottsága, az etetési és gondozási müveletek révén, válik akarva nem akarva, érdemben, lélekben is a sérült gyerekének szülőjévé.

\section{Partneri-e a kapcsolat szülö és szakember között?}

Jó esetben a segítő szakemberek, a gyógypedagógusok és a gyógytornászok, a szülőknek partnerei a szónak egy bizonyos értelmében. Együttműködnek, együtt, egymással fáradoznak azon, hogy a sérült gyermek minél jobban fejlődjön. Viszont nem minden vonatkozásban partnerek. A szülőket maga a sors sújtja, a heti 168 órában. A 
szakemberek legfeljebb hivatástudattal ugyan, de fizetésért dolgoznak velük, nagyjából munkaidőben, és gyerekenként egy, vagy néhány órában. A szülő és a szakember viszonya ez alapján egy bonyolult folyamat, amelyhez nem csak a közvetlen kommunikációs nehézségek, hanem a két fél képzeletvilága és tudattalanja is beletartozik.

Viszont mind a két felét sújtják a gyermekkel kapcsolatos dilemmák. A szülő nem ritkán él meg magánproblémái mellett identitásválságot is. A szakembert feszíti a munkakör határa, ki- és belép kliensei életébe, lehetőleg munkaidőben. Tartja a kapcsolatot a családokkal úgy, hogy ő húzza meg a határokat, pl. arra vonatkozóan, hogy lehet-e őt munkaidőn kívül felhívni, vagy nem. Nem mindig teszi ezt meg könnyen. A fiatal családok e korai szakaszában, amikor bajba kerülnek a szülök, mert nem fejlődik a gyermekük jól, sok - még meg sem fogalmazott- vegyes érzésekkel lehetnek tele, s még nagyon nehézzé válhat a helyzetük. Mindezeket a szülői történeteket érzékelheti a szakember, amiért munkája jócskán megnehezülhet, és munkaidőn kívül is foglalkoztatja őt.

\section{Terápiás jellegü-e a kapcsolat?}

A szülö-szakember kapcsolat kezdetben tulajdonképpen kölcsönös tapogatódzás. A korai intervenciós központok gyakorlata, hogy a kórházban végzett orvosi diagnosztizálási folyamat után, vagy azzal párhuzamosan néhány különbözően képzett szakember (szakorvos, gyógypedagógus, mozgásterapeuta, pszichológus) alkot komplex véleményt a gyermek állapotáról, és arról, hogy a gyermek fejlődése hogyan lesz majd a leginkább befolyásolható, serkenthető vagy korrigálható. Jellemző, hogy a szülők egy ilyen komplex kivizsgálás után ritkán mondanak nemet a felkínált terápiáknak, a sokk hatása - mely szerint az ő gyerekük fejlesztésre szorul, hogy valami nincs rendben - nagy, s egy ideig eltart. Idővel azonban kételkedni kezdhetnek, vagy túlzott elvárásokkal kezdhetnek bele a közös munkába.

Ez a kommunikációs „gubanc” kezdetben még elég természetes, nem elkerülhető, de a fejlesztések során sok dilemmát okozhat a fejlesztő szakembereknek. A felek nem csak egymással jöhetnek ki nehezebben, amikor a szülö bizonytalan abban, hogy amit mondtak vagy mondanak neki a gyermekével kapcsolatban, igaz- e, vagy sem, hanem különbözőképpen értékelhetik a fejlesztés hatását is. S közben sok új kérdés vagy dilemma is megfogalmazódhat a szülőkben, aminek megbeszélésére a fejlesztéseken belül nincsen igazán lehetősége. Idővel joggal felmerülhetett a kérdés tehát: nem kellene a korai fejlesztés keretén belül lehetőséget adni ezeknek az információknak, és/vagy változó gondolatoknak a megbeszélésére? Lehetne talán korai fejlesztés címszó alatt beszélgetni is és fejleszteni is?

A tapasztalatunk az, hogy „eset” és életkörülmény - mármint, hogy a szülők életkörülményei - válogatja meg, hogy ez a választási lehetőség kedvező-e, vagy nem. Amikor viszont kiderül az, hogy a szülőnek szükség lenne arra, hogy többet beszélhessen az ő gyermekét fejlesztő szakemberrel, fontos, hogy ez a szükséglet, s az esetleg ezt követő váltás az együtt töltött idő tartalmára vonatkozóan megfogalmazódjon, hogy sem a szülő, sem a szakember ne érezze úgy, hogy ők a gyermek idejében beszélgettek vagy beszélgetni fognak egymással. Tapasztalataink szerint a szülöknek óriási igénye van arra, hogy a gyermekükkel kapcsolatos mindennapi dilemmáikat a gyermeküket fejlesztő szakemberrel megbeszélhessék. Hiszen a szülők szemében ők értenek a mássághoz, s néha ők az egyedüli személyek, akik a gyermekük másságát teljes mértékben elfogadják a normálisnak egy variánsaként. Hiszen a természet, az élet velejárója hogy ennek kialakulásában és hiba történhet. 


\section{Milyen jellegű tanácsadásból profitálhat a szülő a leginkább?}

Egy fontos szempont, amikor a fejlesztés időlegesen vagy állandóra átmegy nevelési tanácsadásba, hogy a beszélgetéseknek legyen konkrét tárgya, témája. E szemponttal megelőzhetjük szülő és szakember bizonytalanságát azzal kapcsolatban, hogy mit mondhatnak egymásnak, meddig mehet el a beszélgetés, hiszen akarva nem akarva de minden beszélgetésnek van egy bizonyos mélysége. Ez nem azt jelenti, hogy egy szülő nem öntheti ki egyszer-egyszer a „lelkét” is a szakembernek, hanem azt jelenti, hogy az ilyen történet egyedi esemény kell hogy maradjon. A hivatalos keret, a tanácsadásra való szükséglet megfogalmazása, lehetővé teszi mind a két félnek azt, hogy egy következő alkalommal a fejlesztésről szóló napirendre visszatérjenek. Amikor kiderül viszont az, hogy a szülő legnagyobb problémája az, hogy a gyermekét érzelmileg elfogadja, pszichológus segítségére van szüksége.

A leginkább a gyógypedagógusok lesznek azok a szakemberek, akik számára az említett dilemma, fejlesztés és/vagy tanácsadás, gyerekenként, családonként felmerülhet. A gyógytornászok inkább „védettebbek”, az ő fejlesztő programjuk könnyebben élvezi a szülők tiszteletét, mint a gyógypedagógusok fejlesztő játéka, amit a szülő nem könnyen különböztet meg a saját, gyermekével kapcsolatos játékos tevékenységétöl. A szülő és szakember között kötendő szerződésben a kétféle intervenció, a fejlesztés és a tanácsadás, akár fel is válthatják egymást, feltéve hogy a szülő számára egyértelmű e helyzet. Nem a szakember, hanem a szülő dönt ebben. A szülő legyen meggyőződve arról, hogy a beszélgetések alapján éppen úgy nyerhet hasznos információkat, gondolatokat, ötleteket, mint amikor tanúja annak, hogy mivel és hogyan fejleszti a szakember a gyermekét. S bár javaslatot tehetnek arra, hogy szakemberként melyek témákat gondolnak aktuálisnak, nem érzetethetik a szülővel azt, hogy ők mit szeretnének a leginkább. Ha a szülő nem szeretne rendszeresen beszélgetni, az otthoni életéből információkat átadni, marad a remény, hogy a gyógypedagógus szemlélete és magatartása indirekten, a fejlesztések során is fejti ki a hatását a gyermek nevelésére.

$S$ mit kell a gyógypedagógusoknak tanulniuk, hogy a fejlesztés mellett erre a másik intervenciós formára is merjenek vállalkozni? Miben szólhatnak bele, ha a szülő erre igényt tart, és hol vannak a határok, tekintettel arra, hogy nem pszichológusok az illetők? Bár a cikk nem alkalmas arra, hogy erre a kérdésre részletes választ adjunk, a továbbiakban csak néhány alapgondolatot és némi információt közlünk. ( $A$ cikk nem tartalmazza részletekben a tanácsadás módszertanát, valamint a tanácsadás lehetséges területeit. Speciális tanfolyamok szerveződnek a szakmai kompetencia ilyen jellegü bővítéséhez. Részletes listát lásd a honlapon: www.koraifejleszto.hu).

\section{Milyen többlettudást igényel a gyógypedagógiai tanácsadásban való jártasság?}

Pontokba szedve a gondolataimat próbálok erre válaszolni.

- A tanácsadásra vállaló gyógypedagógusoknak többet kell tudniuk a sérült gyerekeket nevelő szülők családi életéről, mint amennyire ezek a problémák már az alapképzésük során szerepeltek a tananyagban. Ez több pszichológiai tudást jelent, ún. alkalmazott pszichológiát. A szakemberek - legyen gyógypedagógus vagy gyógytornász- tanuljanak rendszerszemléletben gondolkodni, megélni minden családtag megnehezített sorsát a természetes összefüggésekben. Az annak idején tanult ismeretanyagot, a sérült gyerek szülei pszichológiai és társadalmi helyzetével kapcsolatos problémáit tudjon gyerekenként továbbgondolni. A már továbbképzett szakemberek legyenek tisztában a kiscsalád-nagycsalád viszonyrendszerével, értsék a testvérek helyzetét, a házaspár veszélyeztetett, vagy már megváltozott viszonyát stb. 
- A szakemberek legyenek tisztában a korai fejlesztéssel szűk értelemben véve, vagyis legyenek már jártasak a szülőkkel és a gyerekekkel való kapcsolattartásban. Elegendő szakmai és élettapasztalatra van szükség tehát, mielőtt egy tanácsadás elkezdődhetne. Miközben továbbképzik a szakemberek magukat, tanulják a tanácsadás módszertanát. Ez azt a célt szolgálja, hogy munka közben már a „saját” családjairól fogalmazódhatnak meg gondolatok esetleges tanácsadással kapcsolatban.

- Gyarapodjon a szakemberek önismerete. Ha a szakemberek az érzelmeikkel való gazdálkodásról többet tudnak, ha szupervízióval dolgozhatnak, egyre jobban érthetik meg a saját müködésüket, gyarapszik az önismeretük. Ez a tudás itt nem elsősorban a szülőkre vonatkozik tehát. A szakembereknek tudniuk kell, hogyan bánunk általában érzelmeinkkel. Tudniuk kell, hogy magánemberként, önmagukat védve, sok érzést nem szeretnénk magunkhoz engedni. Természetes folyamatok ezek: tagadjuk, vagy átminősítjük az érzelmeinket, még mielőtt felismernénk őket. Szükség van arra, hogy a primer, a helyzet kiváltotta lehetséges érzelmekről is tudjanak, ami tudni lehet.

- Szükség van arra, hogy a szakember konkrét tudnivalói is gyarapodjanak. Speciális tanfolyamok révén tájékozottá válik abban, hogy otthonukban hogyan élnek a másképpen fejlődő gyermekek, s konkrétan milyen speciális gondozási és nevelési gondokkal küzdenek a szülők. E tudás kiindulópontja az egészséges, jól fejlődő gyermekről szóló fejlődés-lélektani és nevelés-lélektani tudás, de ez a tudás nem elég. Csak akkor értjük meg a sérült gyerekek és szüleinek mindennapi gondjait, ha területenként foglalkozunk a fejlődés és a nevelés lehetséges dilemmáival, s azzal, hogy azok milyen speciális bánásmódot igényelnek. Milyen evési, alvási problémák fordulhatnak elő például, hogyan lehet a magatartási gondokat kezelni, amikor a gyermek nehezen irányítható vagy alig motiválható? Fel kell készülni arra, hogy sok szülö gondja az, hogy nehezen dönt abban, vajon a sérült gyerek mikor és miben éljen együtt a család többi tagjával, és milyen helyzetekben mennyire indokolt, hogy saját napi és heti rendje legyen?

- S magának a tanácsadásnak saját módszertana is van. Ezeket az alapokat ismerni és alkalmazni kell. Nem nevezhetjük a gyógypedagógiai tanácsadásokat szülőterápiának, annak ellenére, hogy a tanácsadások terápiás jellege óriási lehet... Speciális továbbképzések alakultak azzal a céllal, hogy a fenti szempontok alapján felvértezzék az erre igényt tartó kollégákat (www.koraifejleszto. hu).

- Tágabb értelemben is tanulni kell az emberi kommunikációval kapcsolatban az alapvető ismereteket. A szülővel való együttműködésben az előforduló „gubancokat" meg kell tudni találni, s alapszinten megnevezni, majd kezelni is őket. Tranzakció-analízisben gondolkodva jó esetben mind a két fél, a szülő és a szakember, szeretne kapcsolatfelvételkor felnőtt pozícióból indulni, viszont már valamelyik fél első kezdeményezése, pl. a tegezés lehet ennek akadálya. A szakembereknek át kell látniuk a felek különböző pozícióiból adódó nehézségeket, amikor együtt szeretnének müködni. Fel kell ismerniük, hogy mit hogyan, milyen pozícióból üzenjenek egymásnak? (Steward és Joines, 1994, Borbély, 2012. 165-187. о.)

- A pozíciókkal való játszmázás nagyon jellemző lehet a korai intervenció terén. Játszmák, amelyekre a szülő is és a szakember is úgy érzi, rászorul. Mind a két fél rendszeresen kényelmetlenül élheti meg magát a saját pozíciójában, annak ellenére, hogy közben örül is a kapcsolatnak, és kedveli is egyben a szakembert. Viszont nem szívesen fogadja a viszonylagos függőségét a másiktól. Ezért van az, hogy szívesen tegeződne, vagy tegezi a szakembert. A két fél közti korkülönbség hiánya önmagában is lehet akadálya annak, hogy a kapcsolat gördülékeny legyen, vagy éppen maga a nagy korkülönbség lehet az, különösen, amikor a szakember a fiatalabb fél. 


\section{Fejlesztés és/vagy tanácsadás}

Mikor szorul egy család, egy szülő speciális tanácsokra? Mikor nem elég a korai fejlesztés hagyományos formája: a gyermekek értelmi, mozgás- és/vagy beszédfejlesztése speciális gyógypedagógiai programok révén?

E kérdés megválaszolásához szükség van arra, hogy belássuk: akármilyen ügyes is a szakember, a fejlesztő órákban átadott tudás csak akkor lesz eredményes a hét egyéb óráiban, amikor a gyermek szülője is felfogja azt, ami az órában történik. Ez nem történik meg automatikusan. Egy szülö könnyen felfoghatja a korai fejlesztést úgy, mintha a gyermek egy vagy néhány órában iskolába járna, s neki más dolga nem lenne, mint a gyereket vinni és hozni. Pedig ez nem így van. Nem arról van szó, hogy a szülők házi feladatra szorulnának. Ilyen elvárás csak bizonyos mozgásterápiák esetében fogalmazódik meg. Helyette belső, ún. intrinsic motivációra van szüksége ahhoz, hogy a két felnőtt a gyerekkel együtt, egymást kiegészítve, táplálhassák egymás tudását. A korai fejlesztés csak akkor lehet eredményes, amikor egy szülőben megjelenik a belső motiváció arra, hogy meg akarja tudni és megérteni, hogy mit miért csinál a szakember, milyen szándékok, milyen gondolatok vezérlik őt a tananyag kiválasztásában és a módban, amiben a gyerekkel szeretne együttmüködni, együttdolgozni. A szülö szeretne hozzájárulni a gyermeke teljesítményeihez. Jó, ha nem tanárként szeretné ezt, hanem szülőként, nem házi feladatot végezve, hanem megértené a serkentés, a módszer és a tananyag lényegét. A tanácsadás segíthet abban, hogy ami a fejlesztés során történik, lefordíthatóvá válik a mindennapos helyzetekre.

\section{Helyzetek, amiben a tanácsadás a leginkább hatékony lehet}

Egy szülő gyakran azt éli meg, hogy a fejlesztő szakemberrel töltött órája alatt „dolgozik" a gyermeke, de ő otthon nem éri el az aktivitásnak e szintjét. Azt éli meg, hogy otthon az optimális tanulási helyzet ritkán adódik meg spontánul. Egyedül nem találja meg a mindennapi tevékenységek során - a gondozási müveleteket is bekalkulálva- a lehetséges fejlesztési vagy nevelési mozzanatokat. Közben éppen a gondozási müveletek olyan kommunikációs helyzetek, amelyek igen alkalmasak arra, hogy a szülö ezekben több tudáshoz és nagyobb önállósághoz segítse a gyermekét. A fejlődésében elmaradó gyermek, vagy a másképpen fejlődő gyermek ezekben sokat tanulhat, amikor az ő cselekvései, illetve a szülő cselekvéseire adandó válaszai elvárhatóvá és megszokottá válnak.

Az is előfordulhat, hogy a szülő a fejlesztések során nem találja a maga szerepét, s nehezen marad háttérben. Fejlesztés közben szól a szakembernek, vagy figyelmezteti a gyerekét, amikor éppen csak figyelni kellene. „Segíteni” szeretne a szakembernek vagy a gyerekének, amikor ez éppen nem kívánt.

Igaz, a fordítottja sem ritka. Előfordulhat, hogy egy szülő fáradt, amiért fejlesztés közben inkább a folyosón marad. Óra közben netán telefonos ügyeket szeretne intézni, nem értve azt, hogy a fejlesztő óra neki is szól.

Ha egy szülő nem érti a fejlesztés lényegét és nincsen jelen az órán, nem várható el, hogy a gyógypedagógiai óra fejlesztő hatással legyen. A fejlesztésében elmaradó gyermek segítség nélkül nem lesz képes arra, hogy amit a fejlesztő órán megtanul, otthon is alkalmazza. Automatikusan nem lesz a tanultaknak ún. transzferhatása. Ez csak akkor léphet fel, amikor a szülő otthonában megtalálja a napirendnek azokat a mozzanatait, amibe beépítheti az órán tanultakat. 


\section{A korai fejlesztés, mint félreértések forrása}

Mi történik tulajdonképpen a korai gyógypedagógiai fejlesztési órák során a kommunikáció szintjén, amikor a találkozások formálisak? Milyen jellegü információ cserél gazdát, amikor nem tisztázódik a lényeg? Mi hangzik el azokban az órákban, időszakokban, amikor a szülök a gyermekükkel együtt vannak a fejlesztő szakemberrel, de a felnőttek érdemben nem kommunikálnak? Adva van pl. egy gyógypedagógus, aki formális kapcsolattartásra törekszik a szülővel, mert erről szól a szerződése a szülővel: a gyermek szorul fejlesztésre, nem a szülö. Milyen lehet itt a metakommunikáció a felek között, amikor olyan sok mindent nem mondhatnak egymásnak? Milyen lesz a két fél mondataival nem mindig szinkronban lévő kísérő gondolatoknak és érzéseknek a tartalma? S mit jelentenek valóban azok a mondatok, amelyek elhangzanak, s amelyek könnyen félreérthetök? Amikor óra közben a gyógypedagógus pl. ügyesnek és okosnak nevezi az értelmileg sérült gyereket, mert önmagához képes az. Mit gondol, gondolhat ilyenkor a szülö? Talán azt, hogy ezek szerint meggyógyul majd a gyereke, behozza az elmaradást?

A szakember dilemmája tehát valóban az, hogy meddig mehet el a dicséreteivel úgy, hogy a szülőnek reális képe maradjon a gyermekéről. Igaz, az idő folyamán kontrollvizsgálatok lesznek, s nem valószínü, hogy a szülők az ilyen vizsgálatok után azt fogják hallani, hogy hála a fejlesztéseknek a gyermekük meggyógyult. Jó esetben az hangzik majd el, hogy a gyermek, a meglévő problémák súlyosságához viszonyítva, „tartja a tempót”. Jól fejlődik tehát, de szubjektíven, a szakemberek által felállított, a gyermekre szabott egyéni paraméterek alapján. Ez a konfrontáció könnyen ronthat a szülő és a fejlesztő szakember közötti kapcsolaton.

A szülő dilemmája tehát az, hogy mennyire engedi magát a szakember bíztató szavaival félrevezetni. Hiszen úgy szeretné elhinni azt, hogy gyermeke valóban ügyes és okos, máskor legfeljebb lusta vagy álmos. A szülő környezete folyamatosan tükröt tart neki, tudatja vele vagy mutatja neki, hogy az ő gyermeke „más”: fejlődésében elmarad, vagy eltérő fejlődést mutat. $S$ most itt van végre egy gyógypedagógus, vagy másik segítő szakember, aki fantáziát lát a gyermekében!

E dilemmák miatt szerveződhetnek a kapcsolatban a játszmák, kaphatnak a mindennapos mondatok sajátos jelentőséget, és kerülhet bajban a szakember. Leginkább a két felnőtt közötti interakció adja a helyzet dinamikáját, a gyerek maga annyiban bonyolíthatja a kommunikációs helyzetet, amennyiben ottléte neki egészen más miatt fontos, mint a felnőtteknek. Ő leginkább azon van, hogy ott ahol éppen van, jól érezze magát, különösen ott, ahol a felnőttek vele foglalkoznak. Nincs tisztában a felnőttek gondjaival, csupán a légkört érzékeli. A szakember „lavíroz” a gyermek vágyai, a szülő mondatai, feltételezett gondolatai, és a fejlesztés céljai között, ritkán foglalkozik saját - a kommunikációs helyzettel kapcsolatos- nehéz érzéseivel. Általában csak akkor éli meg a helyzetét terhesnek, amikor a szülő üzenetei, észrevehető érzései olyan erősek, hogy a kimondott vagy ki nem mondott gondolatokból úgy érzi, hogy munkája elveszíti értelmét. Amikor reagálni kell, mert a szülő kvázi provokálja őt. Kézenfekvő magyarázat ilyenkor a szülő pszichés állapotára való hivatkozás: a szülő a sikertelenség oka, mert nem fogadja el a gyermek fogyatékosságát. Jó lenne, ha pszichológushoz menne...

\section{Csak a pszichológus tudna segíteni a szülőknek?}

Egy pszichológus csak akkor tudna talán segíteni, ha a szülő igényli őt, nem amikor a gyógypedagógus úgy gondolja... Amikor viszont a nem pszichológus szakembernek is van, vagy lehet olyan speciális tudása a sérült gyerek nevelésével kapcsolatosan, 
ami beszélgetések tárgyává válhat, akkor nem fogja kerülni a szülő nehéz lelkét, hanem elébe fog menni a vágyának, hogy beszélgessenek az ő speciális problémáiról. Nem az elfogadás, vagy nem elfogadás lehet a beszélgetéseknek tárgya - az lenne a pszichológusi feladat -, hanem a szülő megnehezített helyzete, ennek konkrétumai a mindennapokban. Hogyan lehet a gyermek speciális igényeit úgy kielégíteni, hogy az nem, vagy minél kevésbé akadályozza meg a család, a szülők és testvérek életének minőségét? Hogyan lehet gondozás és nevelés közben is fejleszteni őt? Jelentősen különbözik a gyógypedagógus vagy gyógytornász tanácsadó munkája a pszichológus munkájától. Még csak kevés „érintett” szülő kíván e korai szakaszban pszichológusi segítséget önmagának. Általában még nem tartanak ilyenkor ott, hogy a maguk személyes problémájukat megfogalmazhatóvá szeretnének tenni. Még csak a gyermekük gyógyulására vagy jelentős javulására helyeződik ilyenkor a hangsúly.

A szülő ebben a korai szakaszban küzdve, a nem kívánt tényeket hárítva, úgy éli meg a saját helyzetét, hogy csak a gyereke révén vannak neki gondjai. Nem vele, hanem a gyerekével van baj, tehát csak vele kell dolgozni! Igaz, mint láttuk, nem ritka, hogy a szülő a viselkedés szintjén jól együttmüködik a szakemberekkel, de végig bizonytalanul bízik bennük. Amikor ráadásul nem gyógyul meg a gyermeke a kezük között, idővel sem fogalmazza meg gondolatait, reményeit és félelmeit. Fél a szembesüléstől, hogy gyermeke sérült marad. „A remény hal meg utoljára”, mondja néha az a szülö is, aki teljesen biztos lehet abban, hogy ami az ő gyermekével történt, nem visszafordítható.

Mégis, csak ő maga döntheti el, hogy mikor tart ott, hogy már másképpen is szeretné látni a gyermekét, és így a maga helyzetét is. A nem orvos vagy pszichológus szakemberek nem eröltethetik a realitásokkal való szembenézést, nem konfrontálhatják a szülöket azzal, amivel még nem képesek együtt élni. Orvosok és pszichológusok is csak abban a mértékben tehetik azt, amely szükséges ahhoz, hogy a gyermek ne maradjon ki a rá mért kezelésből, nevelésből, fejlesztésből. A szülők a kezdeti szakaszban emberséges közlések mellett is szívesen, gyorsan „elfelejtik” azt, ami véleményként, diagnózisként elhangzott, de számukra még elfogadhatatlan tények azok. S előfordulhat az is, hogy végig, miközben "használják” a segítő szakembereket a fejlesztéshez, a még nem elfogadható diagnózis miatt távol tartják őket maguktól. Nehéz helyzetek ezek. Ilyen esetekben csak fejleszthet a szakember, s közben szorulhat szupervíziós segítségre.

\section{A tanácsadás lehetséges területei}

Tanácsokat lehet adni a szülö és a gyermek mindennapi életéhez tehát, a konkrétumok, a napirend szintjén. Ez egyszerübbnek hangzik, mint amilyen valóban, mert jó esetben nem csak egy gyermek és egy szülő él együtt, hanem apa is van, testvérek is vannak, a tágabb családról már nem is beszélve. A szülő sérült gyermekével való mindennapi életében jó esetben a többi családtagnak is fontos szerepet jut. Gyakori dilemma az, hogy a szakember nem a sérült gyerek, hanem a többi családtag érdekében adna tanácsokat. Könnyen élheti meg azt, hogy a család élete túlzottan az „érintett” gyermek speciális szükségletei alapján szerveződik, hogy a többi családtag érdekei elhanyagolódnak. Ezt a dilemmát a szülők is érzékelhetik, de amikor szervezik a saját életüket az érintett gyerek körül, ezt nem ritkán a gyermekük vágyott gyógyulása érdekében teszik. A „Minél több annál jobb” nem érvényes szlogen még sok családban most is tartja magát. Sok testvérnek meg kell élnie, hogy - mióta a kis húg vagy a kis öcs megszületett úgy, hogy ennek valami baja van- ezt neki tudomásul kell vennie. 
Miatta már nem fontos az, hogy ő, a nagyobb testvér, milyen ügyesen táncol, milyen okos, vagy hogyan focizik. Merthogy mióta neki testvére megszületett, családjában minden már csak a problémás gyerekről szól.

Rendszeresen előforduló gondok, hogy a gyerek, akivel gond van, amiért sokat foglalkoznak vele, már egyáltalán nem játszik otthon egyedül. Étvágytalansága vagy fokozott válogatóssága, rágási gondok, alvási problémái, mind kerülhetnek megbeszélésre. Sok szülői kérdés a gyermek reakciórepertoárjára fog vonatkozni: nem értik meg azt, hogy a gyerek miért nem csinálja azt, amit elvárnának tőle? A főprobléma, amiért lassabban vagy eltérően fejlődik, a beszélgetések során konkrét arcot kaphat. A szülő annak ellenére, hogy látszólag tudomásul vette azt, hogy gyermeke másképpen fejlődik majd, mégsem képes arra, hogy a megállapított baj függvényében lefordítsa magának, megértse a gyermeke minden megnyilvánulását. Igaz, a fordítottja is elképzelhető: ti. az, hogy csak a szülö érti meg igazán a gyereket, s a szakember tanulhat töle. Abban az esetben viszont probléma lehet maga a szülő, vagy a többi családtag érdekének képviselete. mert attól, hogy értjük, még nem kell hogy mindig az történjen, amit a gyerek szeretne.

Nem ritkán fordul elő, hogy a sérült gyerek sokat, vagy folyamatosan követelödzik, éppen szülei bizonytalan magatartása miatt. Hol így, hol úgy reagálnak rá.

Amikor a gyerek otthoni passzivitása a gond, a tanácsadás egyszerüen kinőhet abból a keretből, amelyben szülő és szakember együtt azon vannak, hogy a gyerek minél jobb minőségben élje meg a napjait, akkor, amikor nem szorul éppen gondozásra.

Nem kell, hogy azonnal sok beszélgetésre szerződjenek a felek, és az sem rossz megoldás, amikor felváltva a fejlesztő és a tanácsadós órák váltják egymást. Mind a két fél könnyebben beszélget, amikor tudja azt, hogy a két féle intervenció arányát ők együtt határozzák meg, nagyjából a szülők igénye szerint.

\section{Amikor a tanácsadás aktuálissá válik}

\section{Otthon nem játszik}

A fejlesztési órákon elsősorban a gyermek játékos aktivitásának elősegítése és fejlesztése a cél. Nem ritkán történik azonban az, hogy a szülő megjegyzi a szakembernek: „Szép-szép, amit maga itt csinál a gyerekkel, de higgye el, tőlem nem fogadja el ezt a játékot, ezt a stílust, otthon". Már itt van egy lehetőség arra, hogy a szakember ezen elgondolkodjon, és a szülővel együtt keres e szempontból egy jobb helyet és/ vagy helyzetet, egy optimálisabb napirendet a gyerek és a szülő számára. Sok szülő nem tudja, hogy nem ajánlott pl. „csakúgy” elkezdeni játszani a gyerekkel, amikor neki éppen egy kis ideje van, vagy amikor nyügös a gyermek. Az együttjátszást be kell építeni a napirendbe. Gondozás vagy alvás után, amikor a gyerek „friss”, kipihent, akkor elsősorban azon kell, hogy legyen a szülő, hogy a gyereke az ő segítsége nélkül aktív legyen, hogy vonzza őt a játszóhelye a benne lévő tárgyakkal. Akkor is, amikor a saját játéka sztereotip lesz, vagy szegényes. Az „érintett” gyereket arra nevelni kell, hogy a szülő nem mindig, és nem csak az övé, s a szakember ebben segíthet a szülőnek. Továbbá: ahhoz, hogy a gyermek jól érezhesse magát a tárgyak között, fontos, hogy az otthoni játszóhelye előkészített legyen, hogy a szülő válogasson a játékszerek között, és mindennap egy kissé másképpen kínálja azokat. A játékhely legyen viszonylag tágas és csábító. Lehet dobozból is játszani, de amikor a gyermek fantáziája korlátozott, otthon is fontos lehet a játékpolc. Ezek mind olyan szempontok, amelyeket a szülö ritkán gondol végig. S ami az együttjátszást, az otthoni fejlesztést jelenti: a szülőnek akkor érdemes a gyerekkel játékosan foglalkozni, amikor ennek természetes vége lehet 
utána, mert evés, alvás, vagy séta lesz a következő napirendi pont. Amikor a szülőnek ilyen alapszempontokat ad a szakember, a szülö egy fix napirendre taníthatja a gyermekét, s ő maga nem veszi észre, hogy miközben ő tanítja a gyermekét, a szakember tanítja és támogatja őt.

Minden másság, fogyatékosság a saját dilemmái elé állítja a szülőt. Viszont egy értelmi sérült gyermek is lehet tanulékony ott, ahol a dolgok egymásutániságát ő megszokja. Minthogy egy autista kisgyerek sztereotip játékába is becsempészhetők kis változások. Minden gyermek számára fontos a kiszámíthatóság, de ez a szempont még fontosabb a lassúbb, vagy eltérően fejlődő gyermek esetén. Fontos neki tudni azt, hogy mikor játszik majd vele a szülö, és mikor nem. S a szülő hogyan jelezheti a gyermekének azt, hogy mi az, ami nem sokára történni fog, ami következő napirendi pont lesz? Jó, ha erre is együtt kereshetik a választ.

Igaz tehát, hogy a gyermek otthoni viselkedésének megbeszélése révén is már benne lehetünk egy család életében. Fontos ilyenkor felmérni azt, hogy ez a „bent levés" mennyire feszélyezteti a szülöt. Ezért van az, hogy ilyen jellegü beszélgetésekre csak néhány alkalomra érdemes szerződést kötni. A szülő kiléphessen e helyzetből, ha ki akar lépni.

\section{Egyéb gyakori gondok}

Sok szülő küzd alvási gondokkal és/ vagy evési problémákkal. Gyakran együtt alszanak a gyerekükkel, amitöl mindenki kimerül.

A gyermek a szülő szerint nem eszik eleget, vagy nem eszik azt, ami egészséges lenne. Nem harap, nem rág, vagy az is elképzelhető hogy PEGje, azaz gyomorszondája van, amiröl leszokható lenne, ha a szülő tudná, hogy hogyan is kellene ezt csinálni. Az evés területén a szakembereknek tudniuk kell, hogy a gyermek táplálkozásával foglalkozva a szülőség alapjait érintjük. Egy jó szülő minimum képes arra, hogy a gyermekét megfelelően táplálja, vélekedik erröl a szülő, akár tudattalanul.

Az együttalvás területét érintve szintén a fokozott óvatosság ajánlott. Nem ritkán „megoldódik” egy ilyen kényszermegoldás révén a szülők szexuális élete. A gyermekük ilyenkor szó szerint éjjel nappal köztük van, elválasztja őket egymástól, leszoktatja őket arról, hogy másképpen is lehessenek együtt. Amikor a szülők jelzik azt, hogy ők tudják, hogy ez nem jó, nem kell a problémájukat szexuális problémáként kezelni, továbbadni egy pszichológusnak. Csupán tisztázni velük azt, hogy szeretnének változtatni a kialakult rossz gyakorlaton vagy nem. S ha igen, a kis lépések müvészetében tájékozott szakemberek segítségével megtanulhatják azt, hogy a jelen helyzetet kis lépésekben megváltoztatva minden gyermek tanulhat éjszakánként aludni, akkor is ha valami baj van vele.

A gyógypedagógiai tanácsadás különbözik a pszichológiai tanácsadástól. Jelentősége ott van, ahol konkrét problémákból kiindulva a szülőknek konkrét kapaszkodókat ad. Igaz, a felek beszélgetés közben kitérhetnek működésbeli, vagy értékbeli dilemmákra is. A konkrét témakörökben gyakran a kis lépések müvészete a téma, nem úgy általában, hanem konkrétan, egy nevelési, vagy fejlődési folyamatot kis részekre bontva. Amikor a szakember munka közben egy-egy területen szülői ellenállást tapasztal, ezt észlelni kell, s valamilyen formában meg is kell jegyezni. Itt igen fontos, hogy az ilyen megtorpanás megnevezése soha ne legyen bántó egy szülő számára. Ahogyan a lassan, vagy a nehezen fejlődő gyermekek problémáival kapcsolatban is rendszeresen kifejezzük azt, hogy „Még nem tart itt, vagy ott”, a nevelés területén is hasonlóképpen fogalmazhatjuk meg a dilemmát: „Talán még nem aktuális, hogy itt s 
most változtatni akarjunk." A mögötte lévő gondolataink szülővel dolgozva viszont mások, mint amikor egy gyermek még nem tud, vagy akar valamit végrehajtani. A nevelés területén belebotolhatunk a szülőnek egy tölünk eltérő értékrendjébe, amely rendet alapjában véve tiszteletben kell tartanunk. Mégis, egy ilyen természetes szembesülés egy másik értékrenddel a szülöben is ébreszthet új gondolatokat. Amikor a szakember képes megállni, megjegyezve azt, hogy itt talán másképpen gondolja a szülő a dolog jelentőségét, mint ahogyan ő, a szülő jó esetben kíváncsi lesz, és az intervenciós szakembertől meg szeretné azután tudni, hogy akkor mi az, amit a másik fél gondol ugyanerröl.

A jól kézben tartott, de nem szigorúan irányított tanácsadásban a szülő szabadon tanulja a saját nevelési dilemmáit más oldalról is látni, s eszközöket kap ahhoz, hogy azokat tudja másképpen is kezelni.

\section{A közelség távolság, az intimitás dilemmája}

Amikor a szülőknek felajánljuk a tanácsadás lehetőségét, betekintünk, és ezzel bekerülhetünk mások családi életébe úgy, mint ahogy ezt ezelőtt nem tettük. Jó ez?

Igen, kétségtelenül beljebb kerülünk. Egy sérült gyerek családjának helyzete már eddig is sajátos volt, független attól, hogy mennyire lettek más emberek is e rendszernek részei. Eddig is jártak a szülők orvosról orvosra, s a fejlesztő munka is már extra anyagi és energia jellegü „,befektetést” jelenthetett a szülők számára, amely az egész családi rendszert érintette. A „sima” fejlesztés együtt a tanácsadással jó esetben, idővel „megérik a pénzét”- pl. azzal, hogy a gyermek a kívánt tempóban fejlődik, vagy azzal, hogy a szülő jobban megérti, hogy hol tart a gyermeke, vagy azzal, hogy a gyógypedagógus mintája alapján jobban megtanul vele bánni, kommunikálni - de ára is lehet mindennek. Az eredményes tanácsadás érdekében a szülőknek pl. betekintést kell adni a mindennapjaikba, a nevelési dilemmáikba, ami nem mindig könnyű.

Szakemberként fontos tisztázni saját magával, hogy amikor kvázi belép egy család életébe, hol vannak e közelségnek a határai? Miről beszélhetnek, mit választhatnak témának, s meddig mehetnek el kérdéseikkel és válaszaikkal, tanácsaikkal?

A tanácsadás-jellegű beszélgetéseinknek hasonló lehet a célja, mint a fejlesztéseknél, amikor azokat egy rövid beszélgetéssel bevezettük vagy összefoglaltuk, de különbözhet is attól. Különbözik például, amikor miután egy konkrét napirendi pontot már megtárgyalták, egy család szokásrendjével kezdenek foglalkozni, ami elég hamar bekövetkezhet. Például amikor a szakember szerint szükség lenne arra, hogy egy gyermek máskor, s másképpen egyen, aludjon vagy játsszon, mint ahogyan ezt most teszi. Ezek a változások, akarva nem akarva, más családtagokat is érintenek, s a szakember ezért érezheti magát kényelmetlenül a tanácsadói pozícióban. A szülőnek a konkrét nevelési helyzet felvázolásához egy bizonyos szintig ki kell tárulkoznia, hiszen a nevelési gond csak tágabb, de konkrét összefüggésekben lesz érthető.

A szakember belelát egy család életébe tehát. Ez a helyzet más, mint amikor maga a fejlesztés miértje vagy mikéntje a téma. De még akkor is, ha pl. csak arról van szó, hogy egy szülő szeret, vagy nem szeret a gyerekemével együtt aludni, vagy a szülő azt mondja, hogy „Nem szoktunk együtt ebédelni, amúgy sem”, zavarban lehet mind a két fél. Ez az újfajta „indiszkréció” nyomaszthatja a szakembert is, úgy érezheti, ha a szülő már ennyit elmondott, a minimum az, hogy a tanácsaink révén sikeresek legyenek. Azonosulnak a szülőkkel tehát, ami terhessé válhat. 


\section{Értékrendbeli különbségek szülő és szakember között}

Egy szakember közvetlenül nem foglalkozik egy család értékrendjével, közvetetten viszont számtalan lehetősége nyílik rá. Amikor már kialakult a kölcsönös bizalom szülő és szakember között, a szülők felvállalhatják azt, hogy nem tudják, mennyire kell vagy kellene a sérült gyermek érdekeit képviselni úgy, hogy az ne, vagy kevésbé történjen a többi családtag rovására. S az sem biztos, hogy a sérült gyermek érdeke az, hogy szülője folyamatosan vele foglalkozzon.

Bár maga az arányosság-aránytalanság dilemmája gyakran központi kérdés a segítségre szoruló családokban, ez önmagában még sem olyan probléma, amivel elkezdődhet egy tanácsadási folyamat. Túl messzire vis,z $s$ túl kevés a konkrétum benne. A helyzet kevésbé fenyegető, amikor a felek, szülö és szakember, először egy részterületet találnak, amiben sok apró kérdés merül fel. Amikor a szülők pl. tanácsokat kaphatnak arra vonatkozóan, hogy gyermeküknek milyen étkezési problémái hogyan értékelhetők, s ha szükség van rá, miként befolyásolhatók. Amikor beszélhetnek arról, mire hogyan lehet őt otthon is megtanítani, szoktatni, s amikor a kis lépések mögött a szakembernek egy bizonyos szemlélete rejlik, erre könnyebben vevők a szülők.

Mit tegyen a szakember azzal, ha a szülök és a szakember értékrendje különbözik éppen azon a területen, ahol együtt kellene müködniük? Lehet, hogy ez a szembesülés már megtörtént, amikor a szülőket tanították vagy a gyermek funkcióit fejlesztették, de a szülőkkel való egyéni beszélgetésekben élesben kerülhetnek szemben önmagukkal, saját, netán a maguk előtt is rejtett szemléletünkkel. Fontos a szemlélet! Nem csak arról van itt szó, hogy a szakember miként látja a szülöket speciális helyzetükben, hanem arra vonatkozóan is, hogy mi alapján, mit vár el egy szülőtől? Ez az elvárás lehet tudatos, de elképzelhető az is, hogy nem az, hogy az elvárás szerves része a szakember saját értékrendjének.

A szakembernek mankó a saját értékrendje, de nem biztos, hogy az övé másnak is az. Ha pl. úgy gondolja, hogy természetes dolog az, hogy a sérült gyermek érdeke az elsődleges, nehéz helyzetbe kerülhet akkor, amikor olyan családokkal találkozik, ahol ezt másképpen gondolják, vagy fordítva. Elképzelhető, hogy a kapcsolat érdekében vélekedéseit igyekszik visszatartani akkor, amikor ez az értékrendbeli különbség kiderülhetne, de nem biztos, hogy ez sikerülni fog. Egy merev arckifejezés, egy „habozás" amikor a szülő választ vár egy konkrét kérdésre, már elárulhatja a szakembert. Egy olyan dolog is kiderülhet, mint hogy pl. a szülők órákra a lakásba zárják az amúgy magatehetetlen gyermeküket azért, hogy ügyeiket elintézzék. Ebben beleszólhat a szakember? Milyen messze mehet el abban az irányba, hogy a szülő speciális szükségletủ gyermekének felnevelésével kapcsolatosan csupán extra áldozatokat igényelne tőle? Lehet egyáltalán véleménye erről? Hol húzódnak a befolyásolás határai? Lehet, hogy a szülő is másképpen gondolta volna e dilemmát, amikor nem lenne ilyen éles helyzetben.

\section{Ellenállás, vagy értékbeli különbségek megakadályozhatják-e a közös munkát?}

\section{Elsődleges kérdés, vajon tanácsadásainkkal ugyanazt szeretnénk elérni, mint a fejlesztésekkel, vagy mást?}

A nevelési tanácsainkkal átmenetileg több munkát, energiát, gondolkodást igénylünk a szülőktől. A várható eredményeknek köszönhetően viszont idővel csökkenhetnek a nevelési problémák. A tanácsadás befektetés tehát. A tanácsadó beszélgetések révén, ha jól találnak egymásra, a szülők idővel időt és energiát nyerhetnek, életük az 
eltérő fejlődést mutató gyermekükkel az életvezetés szintjén könnyebb lesz. Ha egy adott helyzetben viszont nem értékelik hasonlóképpen egy bizonyos problémát, $s$ a szülő a problémával kapcsolatos teendőket hosszabb távon is másképpen látják, mint a szakember, akkor ezt észre kell venniük: velük is, és önmagukkal is tisztázniuk kell, hogy itt miről van szó: ellenállásról vagy értékbeli különbségröl? Ha azt tapasztalják, hogy a beszélgetéseink során a szülökben sok ellenállás van - pl. amiért másképpen látja, máshol helyezi el a hangsúlyokat a gyermekével és a többi dolgával kapcsolatban, mint ahol ők gondolják - előfordulhat, hogy a tanácsadás nem kezdődhet el, vagy nem folytatódhat. Az erről szóló beszélgetést viszont meg kell szervezni, s mivel ez nem egy könnyű beszélgetés lesz, nehéz lehet befejezni úgy, hogy nem hagyjon rossz szájízt senkiben sem. Mégis, annak ellenére, hogy ez a nehezebb része a munkának, ez hosszabb távon gyümölcsöző lehet. A szülő az ilyen jellegű beszélgetés után is, amikor a tanácsadás tehát nem tud (még) elkezdődni, mégis némi kapaszkodót kap. Belelát abba a sok témába, amiröl lehetne véleményt cserélni. Ezek a dolgok különben nem fogalmazódnának meg.

\section{Összefoglalva}

A gyógypedagógus, aki időt szán a nevelési helyzetek megbeszéléséhez, a tanácsadás kezdetén a szülőnek időt és teret ad ahhoz, hogy elmondja, hogy látja a saját helyzetét, miben van problémája, és szerinte mitől van az. A fejlesztő munka másképpen kezdődik el, a szülő egy másik szakembertől kapott diagnózis után jelenik meg. Mások mondták és mondják a szülőknek azt, hogy probléma van, és hogy hol van. $A$ tanácsadás alapjában véve kompetens szülőt tételez fel, aki tudja és felvállalja azt, hogy segítségre szorul. A fejlesztés nem ritkán tartja a szülőt dependenciájában. Ahogyan aztán a fejlesztő munka közvetetten hat a családi életre - szülője válogatja, vajon tapasztalataiból mennyit enged át a mindennapjaira - a tanácsadás közvetlenül érinti a családi életet. Viszont nem érintheti a szülő vélekedését önmagáról mely szerint ő jó szülő, aki tudja mit szeretne. Amikor egy szülő még ambivalens arra vonatkozóan, hogy megéri-e neki a fáradságot, hogy kitárulkozzon, illetve azt éli meg, hogy a tanácsok gyakorlatba való fordításáért meg kell küzdeni másokkal (férjével, nagyszülőkkel), könnyen látszat együttmüködés jöhet létre közte és a tanácsadó között, aminek nincs értelme. A szülő követheti ilyenkor a kapott tanácsokat, meg nem is. Ez a látszat együttmüködés azt eredményezheti aztán, hogy a tanácsok pozitív hatása elmarad: a szülő nem, vagy nem motiváltan fordítja őket a gyakorlatba, s ezt a gyermek is érzékeli, bármennyire „fogyatékos” is ő. A hatás elmaradása viszont ezután negatív indulatokat szülhet, most már mind a két félben. A szülő aztán végül elmaradhat: a tanácsadás félbe marad.

A szakembernek nem szabad magára venni ilyen jellegű „kudarcokat”. Nem ritkán fordul elő. Gyakori jelenség, hogy a bajban lévő szülő segítséget kér úgy, hogy ő még saját magával sem tisztázta a kérdést: képes-e egyáltalán mások véleményét gondolati-érzelmi szinten „befogadni”, esetleg elfogadni. Elképzelhető, hogy a belső „kontrollja”, az önértékelése még nem engedi meg neki azt, hogy tanácstalannak tudja magát, s hogy csak a ránehezedő külső „kontroll”, családtagok, vagy orvosok, hatására kezdi a szakemberekkel az ilyen jellegü kapcsolatot.

A fejlesztő kapcsolat annyiban szimmetrikusabbnak tűnik, amennyiben az tulajdonképpen egy adok-kapok játék. A szülő időt, energiát és pénzt fektet be, s cserébe gyógypedagógiai munkát kap. A szülő akár hallgathat is fejlesztés közben, azt viszi haza az órákból, amit ő szeretne. Az, hogy mit tesz az órán szerzett tapasztalatokkal, 
magánügye maradhat. $A$ nevelési tanácsadások révén a kommunikációs helyzet, a szülő és szakember közötti kapcsolat nem lehet ilyen bizonytalan. A tanácsok kifejezetten a szülők együttmüködési készségére épülnek. Dilemma, hogy miközben a tanácsokat adó szakemberek belelátnak a szülők kapcsolat- és értékrendjébe, a család müködésébe, ennek a fordítottja kimarad: a szakemberek családi élete nem tárul ki a szülők előtt. Ez olyan aszimmetriát jelent a segítő kapcsolatban, ami ambivalenciát szülhet a szülőben. Kevésbé érett szülök esetében ez az alaphelyzet önmagában megakadályozhatja a sikeres tanácsadást.

Amikor egy korais szakember továbbképzi magát a tanácsadás területén, olvasni fog, tanfolyamot vesz igénybe, reflektálni és mérlegelni tanul, s viszonyulni tud a saját értékrendjéhez, működési módjához. Önismerete bővítése eredményezheti azt, hogy a munkájában egyre jobban érzi majd magát, egyre kompetensebbnek. Ebből profitálhatnak mások is, nemcsak a kliensei. Magánélete is színesebbé válhat ezáltal, érettebb, rugalmasabb személyiség lesz. S végül egyre inkább belülröl megérti azt, hogy semminek nincsen abszolút jó vagy rossz megoldása, és mindenki egy kicsit másképpen láthatja ugyanazokat a dolgokat!

\section{Irodalom}

Balzer B. és Rolli S. (1975): Socialtherapie mit eltern Behinderter. Orientierungen für eine Konzeption im Rahmen eines pszichohigienischen Gemeindeprogramms. Belz, Weintheim und Basel.

Berne E. (1984): Emberi játszmák. Gondolat Kiadó, Budapest.

Berne E. (1997): Sorskönyv. Az emberi játszmák folytatása. Háttér Kiadó, Budapest.

Borbély Sjoukje, Jászberényi Márta és Kedl Márta (2000): Szülők könyve. Értelmileg sérült kisgyermekek nevelése. Medicina könyvkiadó, Budapest.

Borbély Sjoukje és Mózes Eszter (2000): Pszichológiai munka a Korai Fejlesztő Központban. Fejlesztő Pedagógia: pedagógiai szakfolyóirat, 11. (4-5.) 73-81.

Borbély Sjoukje (2003): A korai fejlesztés hatékonysága. Fejlesztő Pedagógia: pedagógiai szakfolyóirat, 14. (1) 51-56.

Borbély Sjoukje (2007): A fogyatékos ember családja. In: Csobay Miklósné (szerk.) A Fecske Szolgálat Kézikönyve. fogyatékos embereket nevelö családok otthonaiban nyújtott időszakos kisérés és ellátás. Kézenfogva Alapítvány, Budapest, 54-82.

Borbély Sjoukje (2012): A szülök és mi. Szakmai és személyes összegzés a korai intervenció alapvető kérdéseiröl és kommunikációs dilemmáiról. Budapesti Korai Fejlesztő Központ, Budapest.

Buda Béla (1994): A közvetlen emberi kommunikáció szabályszerüségei. Animula Kiadó, Budapest.

Buda Béla (2006): Empátia. Urbis Kiadó, Budapest.

Gyertyánági Judit (1995): A fogyatékosság közlésének nehézségei az orvos-szülö kapcsolatban. Szakdolgozat. ELTE Speciális Pedagógia. Neveléstudományi Tanszék

Kálmán Zsófia (1997): Bánatkő. Bliss Alapítvány-Keraban Kiadó Kft., Budapest.

Kedl Márta és Borbély Sjouke (1991, szerk.): Szemelvénygyüjtemény a korai gyógypedagógiai gondozás-fejlesztés témakőréből I. Szemléleti kérdések. Tankönyvkiadó, Budapest.

Kereki Judit és Lannert Judit (2009): A korai intervenció intézményrendszerének magyarországi működése. Fogyatékosság és társadalom. A fogyatékosságtudomány és a gyógypedagógia folyóirata. 2. (2) 189-210.

Kübler-Ross E. (1988): A halál és a hozzá vezető út. Gondolat Kiadó, Budapest.

Steward I. és Joines V. (1994): A TA-MA. Bevezetés a korszerü tranzakcióanalízisbe. Xenia Kiadó, Budapest. 